\title{
ЛITEPATУРОЗНАВСТВО
}

UDC 821.161

DOI https://doi.org/10.32838/2663-6069/2020.4-3/23

Garachkovska $O$. O.

Kyiv National University of Culture and Arts

\section{CHEKHOVSES INTERTEXT IN THE GRIGOR TIUTIUNNIC'S CREATIVITY}

The article is devoted to the analysis of intertextual connections in the novelty of Grigor Tiutiunnic with the work of A. Chekhov as an aspect of the dialogue of cultures. Based on the private epistolary of A. Chekhov, works of art, memoirs of his contemporaries, the genetic connections of the Russian writer with the Ukrainian people and his culture are revealed. The article also uses the private epistolary Gr. Tiutiunnic wanted to cover the intertextual dialogues of the Ukrainian novelistist with an outstanding predecessor in the literature.

An analysis of Chekhov's intertextuality in the work of the Ukrainian writer suggests that the mentally-linguistic phenomenon of Gr. Tiutiunnic belongs to the "local existence" of the carrier of the national culture in the conditions of multiculturalism. Art space of creativity Gr. Tiutiunnic is built on the ground of the key principles of the geopolitical worldview, multilaterally embodied in its diary notes, in epistolary dialogues with friends, editors, publishers. The aimof the article is to analyze the specificity of the functioning of the Chekhov intertext in the work of Gr. Tiutiunnic.

A. Chekhov and Gr. Tobacco do not discuss actions and actions. They are also kept from conclusions. Author's assessments are concentrated in the ability to reflect the truth of life of their time. In addition to the life that accompanied them, both writers asserted more of what he imagined (with the Creator Man). In this we see the essence of author's images, the humanistic energy of the principle of continuity. Understanding Chekhov's Intertext in the Creativity of Gr. Tiutiunnic shows that the mentally-linguistic phenomenon of the artist belongs to the "livelihood" of the carrier of the national culture in the conditions of multiculturalism.

Maternal traditions in the family, archetypal memory of Ukrainian culture became the basis for the formation of a "Russified author of Ukrainian origin". Hence, the free possession of the prose writer in two languages, for example, is a series of works originally written in Russian ("Twilight", "Alesia", "Deaf") and then translated (or freely reproduced) in Ukrainian ("In the Twilight", "Alesya", "Deaf'). Art space of creativity Gr. Tiutiunnic is built on the ground of the key principles of the geopolitical worldview, multilaterally embodied in its diary notes, in epistolary dialogues with friends, editors, publishers. Consequently, intertextuality, one of the most important, most common types of which is the interrelations ("influences") of literatures, is an integral part of the artistic innovation of the Greeks.

Key words: novels, intertextuality, dialogism, tradition, epistolary, multiculturalism, dialogue of cultures.

Formulation of the problem. The Ukrainian prose writer Gr. Tiutiunnic (1931-1980) in many respects updated the content and poetry of prose, deepened the study of Ukrainian national character. However, he inherited a lot of discoveries of both domestic and Russian and world literature. The problem of intertextuality, traditions, continuity in literature is one of the most urgent and to date insufficiently developed in the science of writing. Now the search is in this direction. It cannot be said that it is always productive, but the direction of search itself is productive.
An analysis of the latest research and publications that initiated the solution to this problem. Despite the fact that in recent years a dissertation work by N. Savchyn [2] was devoted to the problem-artistic comparison of the novels of the Greeks. Tiutiunnic and creativity of Russian writers, there is still no comprehensive study of the Chekhov intertext in the work of the Ukrainian prose writer. Consequently, the relevance of the article is caused by the acute need to fill the gaps in understanding the intertextual connections of the novels of the Greeks. Tiutiunnic's activity was creativity A. Chekhov, as well as the lack of publications on this topic. 
The aim of the article is to analyze the specificity of the functioning of the Chekhov intertext in the work of Gr. Tiutiunnic.

Presenting main material. Gr. Tiutiunnic, like no other, noticed abruptly the destructive processes taking place in the morally-customary manner of the Ukrainian people, resulting in the degradation of family and personality, debauchery, drunkenness, "demobilization" of goodness, collectivism, charity (the narratives "Katrin's getting", "Son arrived", "Literate", "Nyura", "Death of the cavalier", the story "Siege"). In the short story "Medal" to the person who dies, and in the village, which just breathes in incense, they hand over the medal "For labor valor".

Lightened face and soul only with children. In the stories "Klimko", "Foam far away in the steppe", in the children addressed to the collections "Lasochka", "Steppe fairy tale" Gr. Tiutiunnic showed himself a thin psychologist, a true connoisseur of the child's soul. The "dialectic of the soul" (both a child and an adult), the writer studied both in life itself and in his predecessors in the literature.

The name of the Russian writer A. Chekhov, in our opinion, should be named among his first spiritual mentors. A. Chekhov's lyrical prose, along with the artistic experience of Ukrainian and Russian classics, was for the novelist a true source of his creative personality. Certain significance was the fact that the author of "Steppe" and "Cherry Orchard" by many pages of his biography and creativity was close to the Ukrainian people and his culture. This is evidenced by the correspondence of A. Chekhov with outstanding Ukrainian artists, and the memories of contemporaries about him, and his works.

The researchers of the artist's work have made many interesting observations in the domain of the theme "Chekhov and Ukraine". The questions addressed to literary scholars include Chekhov's places in Ukraine, Chekhov's connections with the creative intelligentsia, and the Ukrainian national component in the works of the writer. Among the literary criticisms of Chehov's of the last two decades, the work of V. Zvynyatskovsky is drawn in which the researcher finds out the typology of the world's reception in the works of A. Chekhov and M. Kotsiubynsky [1].

In the conditions of Soviet totalitarianism, the precautionary statements of certain scholars about the Ukrainian origin of Chekhov were categorically denied. On the contrary, in the publications of the Ukrainian diaspora scientists, on the contrary, there is a marked desire to isolate (unfortunately, without convincing arguments) Ukrainian pewts in Chekhov's worldview in every possible way. In this regard, the works of such scholars as O. Podolsky, N. Popil, N. Polyanska-Vasilenko and others can be worthy of attention.

All of the aforementioned literary scholars note that, in analyzing Chekhov's life and work in the light of Ukrainian influences and ties, his private correspondence, the memories of Chekhov's contemporaries, and the works of the writer themselves were of prime importance. However, in spite of the attempts of a comprehensive approach to the topic of "Chekhov and Ukraine", in our opinion, it was still not implemented.

Dissertation work by O. Fidkevich "Epistolary Prose by A. Chekhov and ideological and artistic quest for the writer of the 80's and 90's. XIX - early XX centuries" (2006), and in particular, the article by the researcher "The image of Ukraine in the epistolary A. Chekhov [3], and they are devoted precisely to the coverage of such a complex topic as "Chekhov and Ukraine" through the prism of non-isolated letters, and correspondence as a system. One of the directions of this analysis, O. Fidkevich, selects the study of epistolary cycles, which she conventionally calls "Letters from Sumy Region". They were written by the addressee during the stay of Chekhov in Sumy in 1888 and 1889 and addressed to friends and relatives. Attention was also drawn to the previous letters and letters, written later (in Moscow and abroad), in which Chekhov also touched the themes of Ukraine.

So, with the epistolary of A. Chekhov, as well as from the scientific works of the above-mentioned literary scholars, we learn that his children and youths were in Taganrog, on the Azov Sea, where there were many Ukrainians among the population. According to the memoirs of the brother of the writer M. Chekhov, in their family they knew and loved the Ukrainian songs. Thus A. Chekhov, in the childhood, was acquainted with the Ukrainian language and with the life of the Ukrainian people. During his childhood he deepened his knowledge during his travels to Donetsk, Poltava, Kharkiv and other regions of Ukraine. Unforgettable impressions made him travel to his grandfather, who lived in steppe settlements not far from Taganrog. "I love the Donetsk steppe", he writes later. "I once felt in it at home, and I knew every little parchment there. When I mention these gobs, mines, the Saur-grave, the stories about Zuya, Khartsyza, General Ilovaysky, I remember how I was driving in the wolfs in Krinichka and in the Serpent Count Platov, then I find it sad and sad that in Taganrog there are no belletrists and That this material is very cute and valuable, nobody needs it" [3, p. 231]. 
From the very beginning, the reception of Ukraine in the letters of Chekhov acquires a fabulous-folklore character. This perception was prepared by children's memories, first of all memories of the village Knyazhi, where Chekhov spent summer months with his grandfather. The references to this stay are also available in letters from Sumy Region. It is worth noting that the word "lyrics" is the key to shaping the image of Ukraine, which Chekhov creates in the letters. "Lyrical", "poetic", "poetry" these definitions abound in his letters of the late 80's of the nineteenth century.

At the same time, Chekhov's private correspondence also depicts the real picture of Ukraine. For the writer, it is an ideal of naturalness, harmony, physical and spiritual purity, beauty that he so valued. According to O. Fidkevich, the image of Ukraine in the first part of the epistolary cycle "Letters from Sumy Region" has "not so much objective-historical character as conditional aesthetic, similar to the image of Ukraine in the works of Gogol. In the second part of the cycle, this image acquires more specific features and becomes a source of interesting historiographical observations" [3, p. 85].

Noting the talent, sincerity, the mind of Ukrainians, the scenic landscape, Chekhov, however, does not conceal his disappointment over the provinciality of Ukrainian reality. Lack of progress, "grief" irritates him, regardless of national aspect. Chekhov sees the future benchmarks of progress in the values of culture, combined with the talent and spirituality of the people, both Ukrainian and Russian.

We think it is quite logical that interest in the Ukrainian people and their culture has found a versatile expression in many of Chekhov's works. For example, the Donets steppe with its expansive space, fragrant aromas of wormwood and thyme, the original type of Ukrainian peasant Konstantin Zvonik is reflected in the story "Step". With sincere sympathy and soft humor, Ukrainian intellectuals-democrats - brother and sister Kovalenkov in the story "The Man in the Case" were depicted. Memories of childhood, Ukrainian impressions nourished a lot of other Chekhov's works.

It is interesting to note that in the language of Chekhov's heroes from the Ukrainian environment quite often there are Ukrainian direction, typical folk proverbs and sayings. Speaking about the Russian writer in his relations with Ukraine, one cannot ignore the question of the influence of Chekhov's artistic heritage on the development of the creative individuality of the Greeks. Tiutiunnic about the intertextual dialogues of the Ukrainian novelistist with an outstanding predecessor in the literature.
Protecting human in a man, squeezing a slap from a slave by himself - this is the vital credo and the aesthetic ideal that unites the works of A. Chekhov and Gr. Tiutiunnic. The Ukrainian artist was a worthy follower of Chekhov's spiritual teachings. However, it should be noted that the Chekhov traditions, which he continued in his own work, cannot be determined by the principle of only external similarity of phenomena, on the principle of "similarity". They are much deeper, more vital, internally necessary to the art of words.

In a letter to the student of the Faculty of Philology of Dnipropetrovsk State University V. Hrytsenko of April 16, 1977, who at that time worked on the thesis on the topic: "Traditions of A. Chekhov in Ukrainian novelistics". Gr. Tiutiunnic confessed: "I read Chekhov even in the Navy (under Vladivostok) when I was 22 years old and when I had only five-year education all 12 volumes in a row! To understand (as Chekhov writes, according to his traditions, what is its originality, which personality is Chekhov, and even what such "personality" I did not know yet and could not know) but I was very sad. Chekhov is sad writer. Joy is not for the great literature, I quote not exactly, but the thought in these words Chekhov. Joy has never been a companion of literature - a bit more precise. I did not know this statement at that time, therefore, after reading 12 volumes I spoiled myself spontaneously. Subsequently, already being more conscious and literate, A. Chekhov repeatedly re-read in a mess, mixed, selectively - that most enjoyed.

Similarly, by the way like Stefanik, Teslenko and Kotsyubinsky (the story is not "Fata morgana") and Tumanyan ("Gigkor"), and of course, Tolstoy ("Polikushka", "Three deaths", Sevastopol and Caucasian stories) in short, everything that is the best in our, Russian and world literature and world narrative. This study, in the same series and Chekhov, helped me feel the form of the story, its indivisibility (integrity), the intensity of dramatic or lyrical and laconicism; Every word as a bare nerve must react to life in a short story, otherwise it is superfluous" [4, p. 147].

The quoted letter is very telling, in our opinion, for several reasons. First of all, the introduction into the scientific revolution of the researcher O. Nezhivym of unknown previously epistolary materials of T Tiutiunnic brings to us, through the prism of the addresser's reflection, his informal image. Secondly, the given document one of the few today evidence of the Gr. Tiutiunnic about the role of the artistic heritage of A. Chekhov in his life and creative destiny.

From this letter we learn, in particular, about such a dominant prose A. Chekhov, subjectively isolated Gr. The tobacco-maker, first of all, because 
she identifies the tone and his own works, is sum. And, ultimately, the testimony of one of the best Ukrainian novelists, including the brilliant masters of the form, which was Gr. Tiutiunnic, that he was learning to feel his substance primarily in Chekhov, is also quite symptomatic. As a stylist Chekhov is unattainable, at least I. Bunin claimed. So, choosing for the model "inaccessibility", the Ukrainian prose writer had before him a concrete example of realization of human possibilities, which served as a kind of catalyst for him.

In addition to the above letter, in the notebooks Gr. Tiutiunnic also find some phrases from the works of A. Chekhov, the thoughts of the Ukrainian artist about the role and place of the author of "Steppe" and "Cherry Orchard" in forming him as a man and as a writer. Here, in particular, one of the following records: "Chekhov pained and sums for a man" $[4$, p. 47]. And here, say, the Ukrainian writer notes the words of A. Chekhov: "I can only write memoirs" [4, p. 49]. Friends and close people of Grigor almost all remember how he liked to talk about the heroes of not yet written works or to recount excerpts or entire stories about them. Characteristic of his confession: "Fear I like to remember. Each story is under the heart (though I know it) until it becomes memorable to me" (in italics, O. G.) [4, p. 300].

In the stories "On the Fire", "Red Morole" and other memoirs, not only a part of artistic fabric, but also a problem, the concept of a work - it is said that memories, rather, the memory of the yatrets, always knocks in the heart, which, according to the writer, it is the basis of man's spirituality. This idea deeper reflects the consciousness of the Greeks. Tiutiunnic, he notes with pain that many of the compatriots have long been characterized by temporary features, young people lose their sense of dignity, the human soul is subject to corrosion of indifference, national unconsciousness ("Katrin's getting", "Son came", "Soft").

One cannot but notice the fact that both Chekhov and Tiutiunnic are very demanding of the word, extremely cost-effective and economical in artistic means of expression. And it's not about writing as few printed pages as possible. The bottom line was in the other that each page of the work was full of thoughts and feelings. That is why both the Russian and Ukrainian writers created their texts on the principle of brevity, showing a pronounced tendency to stage and linguistic artistry. The ability to write "skilled", "stage" also unites them. This great gift of reincarnation and "play" of human characters and everyday situations was inherent in Tiutiunnic and in everyday life. According to the testimony of many contemporaries and relatives and native writers, the future heroes of his stories and novels, he liked to mimic in comrades' talks, improvising whole scenes, as if checking them, testing them for viability.

By the way, while studying at the Kharkov University Grigor visited not only a literary studio, but also a drama circle. This, in particular, he reported in a letter of September 18, 1957 older brother Gregory [4, p. 24-25]. Finding in the person of A. Chekhov typologically close to him the author, in which the gift of reincarnation was implemented also in the genre of drama, Gr. Tiutiunnic undoubtedly, studied with a prominent great art predecessor to feel another person as himself and to be able to grasp her character with a few strokes.

In Chekhov's works, in particular in his stories, there are whole gallery of characters, the vast majority of which have become types: Unter Prishebiev, a man in a case, a scientist's neighbor, Ionich, the soul, Vanka Zhukov, even Kashtanka. Anna Sergeyevna this is really the usual name of a lady with a dog, endowed with the aroma of a unique person, it's not just beautiful, kind, loving woman, it's a character echoed by the admiration of femininity, and each reader shares the feeling of Gurov. If we turn to the headlines of stories and short stories by A. Chekhov and Gr. Tiutiunnic, it immediately falls into the eye that in both authors the names of works are surprisingly concise, simple, endowed with great potential for further intriguing deployment of the plot.

For example, in A. Chekhov "The Death of an Official", "Thick and Thin", "Disaster", "Joke", "Empty Case". In Gr. Tiutiunnic "Flower", "On the Fire", "Strange", "Markiyan's Memorial", "Katrin's Getting", "Son comes home" and others. Gr. Tiutiunnic formulated for himself the laws of creation of prose based on the Chekhov principle "Brevity the sister of a talent": "To write well means not to write anything superfluous"; "Now, as never before, prose should be laconic to get closer to the oral story". A. Chekhov and Gr. Tobacco do not discuss actions and actions. They are also kept from conclusions. Author's assessments are concentrated in the ability to reflect the truth of life of their time. In addition to the life that accompanied them, both writers asserted more of what he imagined (with the Creator Man). In this we see the essence of author's images, the humanistic energy of the principle of continuity.

Conclusions. Understanding Chekhov's Intertext in the Creativity of Gr. Tiutiunnic shows that the mentally-linguistic phenomenon of the artist belongs to the "livelihood" of the carrier of the national culture in the conditions of multiculturalism. Maternal tradi- 
tions in the family, archetypal memory of Ukrainian culture became the basis for the formation of a "Russified author of Ukrainian origin". Hence, the free possession of the prose writer in two languages, for example, is a series of works originally written in Russian ("Twilight", "Alesia", "Deaf") and then translated (or freely reproduced) in Ukrainian ("In the Twilight", "Alesya", "Deaf").
Art space of creativity Gr. Tiutiunnic is built on the ground of the key principles of the geopolitical worldview, multilaterally embodied in its diary notes, in epistolary dialogues with friends, editors, publishers. Consequently, intertextuality, one of the most important, most common types of which is the interrelations ("influences") of literatures, is an integral part of the artistic innovation of the Greeks.

\section{References:}

1. Звиняцковський В. Я. Новелістика А. Чехова і М. Коцюбинського. Київ : Наук. думка, 1987. 258 с.

2. Савчин Н. Б. Рецепція російської літератури у творчості Григора Тютюнника : дис. канд. філол. наук: 10.01.05 - Порівняльне літературознавство. Київ : Славістичний ун-т. Київ, 2010. 182 с.

3. Фідкевич О. Образ України в епістолярії А. П. Чехова. Київська старовина, 2004. № 4. С. 79-85.

4. «Щоб було слово і світло»: листування Григора Тютюнника / Передмова, упорядкування, примітки, підготовка текстів О. І. Неживого. Луганськ : Альма-матер, 2004. 232 с.

\section{ГарачковсьКа О. О. ЧЕХОВСЬКИЙ ІНТЕРТЕКСТ У ТВОРЧОСТІ ГРИГОРА ТЮТЮННИКА}

Стаття присвячена аналізу інтертекстуальних зв 'язків у новелістиці Гр. Тютюнника з творчістю A. Чехова як аспекту діалогу культур. На основі приватного епістолярію А. Чехова, художніх творів, спогадів сучасників про нього розкрито генетичні зв'язки російського письменника з українським народом $і$ його культурою. У статті використано і приватний епістолярій Гр. Тютюнника для висвітлення інтертекстуальних діалогівукраӥнського новеліста звидатним попередникомулітературі.

Аналіз чеховського інтертексту у творчості украӥнського письменника свідчить про те, шо ментально-лінгвістичний феномен Гр. Тютюнника належить до «помежового існування» носія начіональної культури в умовах полікультурності. Художній простір творчості Гр. Тютюнника вибудовується на трунті ключових засад геополітичного світобачення, багатоаспектно реалізованих у його щоденникових нотатках, в епістолярних діалогах із друзями, редакторами, видавиями.

Актуальність статті зумовлена гострою потребою заповнити лакуни в осмисленні інтертекстуальних зв'язків новелістики Гр. Тютюнника з творчістю А. Чехова, а також відсутністю публікацій із иієї теми. А. Чехов і Гр. Тютюнник не обговорюють дї та вчинки. Вони утримуються і від висновків. Авторські оцінки скониентровані на вмінні відобразити правду життя свого часу. Крім життя, яке їх супроводжувало, обидва письменники стверджували ще й те, яким його уявляли (з Людиною-творием). У иььму ми вбачаємо сутність авторських образів, гуманістичну енергію принципу спадкоємності.

Материнськітрадииїу родині, архетипна пам'ять украӥнськоїкультуристалиосновою становлення «зрусифікованого автора украӥнського походження». Звідси - вільне володіння прозаӥка двома мовами, прикладом чого є низка творів, спочатку написаних російською мовою («В сумерках», "Алеся», «Глухомань»), а потім перекладених (або вільно відтворених) українською («В сутінки», «Олеся», «Глухомань»). Отже, одним із найважливіших, найбільш поширених видів інтертекстуальності є взаємозв 'язки («впливи») літератур - невід'ємний складник художнього новаторства Гр. Тютюнника.

Ключові слова: новелістика, інтертекстуальність, діалогізм, традиція, епістолярій, полікультурність, діалог культур. 